\title{
Novel Neosartorya species isolated from soil in Korea
}

Correspondence

Robert A. Samson

samson@cbs.knaw.nl

\author{
Seung-Beom Hong, ${ }^{1}$ Hye-Sun Cho, ${ }^{1}$ Hyeon-Dong Shin, ${ }^{2}$ Jens C. Frisvad ${ }^{3}$ \\ and Robert A. Samson ${ }^{4}$ \\ 'Korean Agricultural Culture Collection, NIAB, Suwon 441-707, Korea \\ ${ }^{2}$ Division of Environmental Science and Ecological Engineering, College of Life and \\ Environmental Science, Korea University, Seoul 136-701, Korea \\ ${ }^{3}$ Center for Microbial Biotechnology, Biocentrum-DTU, Technical University of Denmark, \\ Building 221, DK-2800 Kgs. Lyngby, Denmark \\ ${ }^{4}$ Centraalbureau voor Schimmelcultures, Utrecht, The Netherlands
}

\begin{abstract}
Phenotypic and genotypic characters of strains of Neosartorya spinosa and related taxa were analysed. N. spinosa, Neosartorya botucatensis and Neosartorya paulistensis had identical partial $\beta$-tubulin and calmodulin gene sequences and could not be differentiated on macro- and micro-morphological characteristics, including by scanning electron microscopy. Based on partial $\beta$-tubulin and calmodulin gene sequences and ascospore morphology, two separate groups are distinguished and are proposed as novel species. Neosartorya laciniosa sp. nov. has microtuberculate ascospores with two bent crests and two distinct equatorial rings of small projections. Neosartorya coreana sp. nov. has rugose to weak reticulate ascospores with two often bent crests, but without the equatorial rings of small projections. The type strain of $N$. laciniosa is CBS $117721^{\top}\left(=\right.$ NRRL $35589^{\top}=$ KACC $\left.41657^{\top}\right)$ and the type strain of $N$. coreana is CBS $117059^{\top}\left(=\mathrm{NRRL}^{35590^{\top}}=\right.$ KACC $\left.41659^{\top}\right)$.
\end{abstract}

\section{INTRODUCTION}

Ascospore ornamentation is an important morphological character for distinguishing species of the ascomycete genus Neosartorya (Kozakiewicz, 1989). Based on ascospore ornamentation, Horie et al. (2003) distinguished homothallic Neosartorya species with white to pale-yellow ascomata and ascospores with two distinct equatorial crests into six species. In this group, Neosartorya spinosa and Neosartorya glabra have been separated on the basis of smooth (for N. glabra) or echinulate (for N. spinosa) ascospores, but many isolates possess intermediate patterns of ornamentation. Furthermore, N. glabra was also reported as highly polymorphic

Published online ahead of print on 21 October 2005 as DOI 10.1099/ ijs.0.63980-0.

Abbreviations: NJ, neighbour-joining; SEM, scanning electron microscopy.

The GenBank/EMBL/DDBJ accession numbers for the $\beta$-tubulin and calmodulin gene sequences of the strains examined in this study are shown in Table 1.

A NJ phylogenetic tree based on calmodulin gene sequences and SEM images of ascospores of Neosartorya species are available as supplementary figures in IJSEM Online.

The Mycobank accession numbers for Neosartorya laciniosa sp. nov. and Neosartorya coreana sp. nov. are MB 500233 and MB 500234, respectively (http://www.mycobank.org). based on secondary metabolite profiles (Samson et al., 1990) and phenotypic and genotypic characteristics (Rinyu et al., 2000).

During a survey of soil-borne Aspergillus and Penicillium in Korea, many Neosartorya strains were encountered and, in order to examine the taxonomic position of our isolates, we have re-examined N. spinosa, N. glabra and related taxa. We have used a polyphasic taxonomic approach in order to determine the delimitation and variability of the taxon. For phenotypic analyses, morphology was examined using macro- and micro-morphology and scanning electron microscopy (SEM) methods and growth temperatures were studied. For the phylogenetic analyses, $\beta$-tubulin and calmodulin gene sequences were used, which have proved to be useful for Aspergillus taxonomy (Feibelman et al., 1998; Geiser et al., 1998; Ito et al., 2001; Varga et al., 2000a, b).

\section{METHODS}

Strains examined are listed in Table 1 . The strains were maintained on malt extract agar slants at $15^{\circ} \mathrm{C}$.

Morphology and extrolites. For macro-morphological observations, Czapek yeast autolysate (CYA), malt extract autolysate (MEA) agar and Czapek agar (CZA) were used (Samson et al., 2004). Yeast extract sucrose (YES) agar, oatmeal agar (OA) and creatine sucrose agar (CREA) were also used (Frisvad \& Samson, 2004). The isolates 
Table 1. List of strains used in this study

CBS, Centraalbureau voor Schimmelcultures, Utrecht, The Netherlands; NRRL, Agricultural Research Service Culture Collection, Peoria, USA; IBT, Institute for Biotechnology, Lyngby, Technical University of Denmark; KACC, Korean Agricultural Culture Collection, Suwon, Korea.

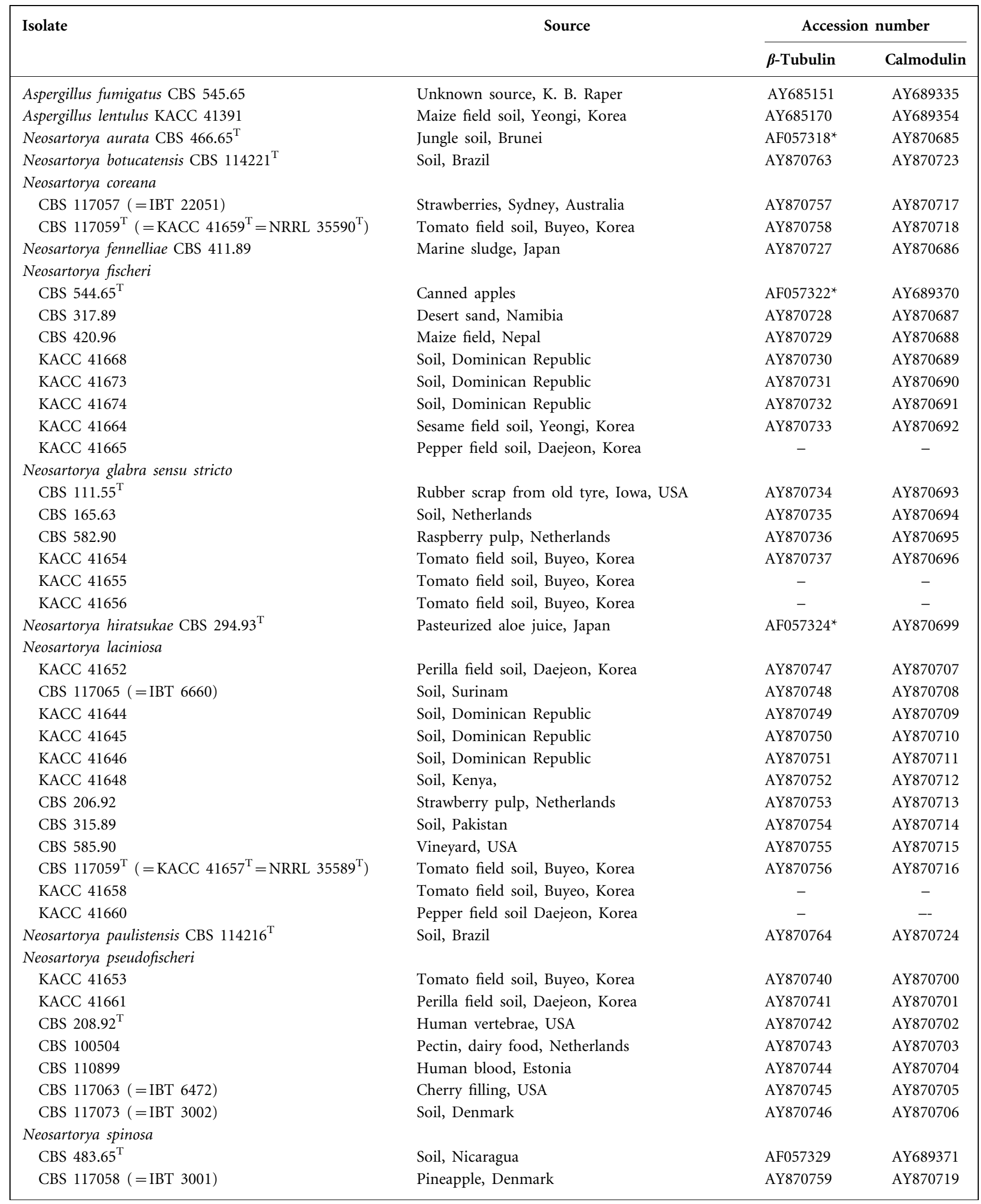


Table 1. cont

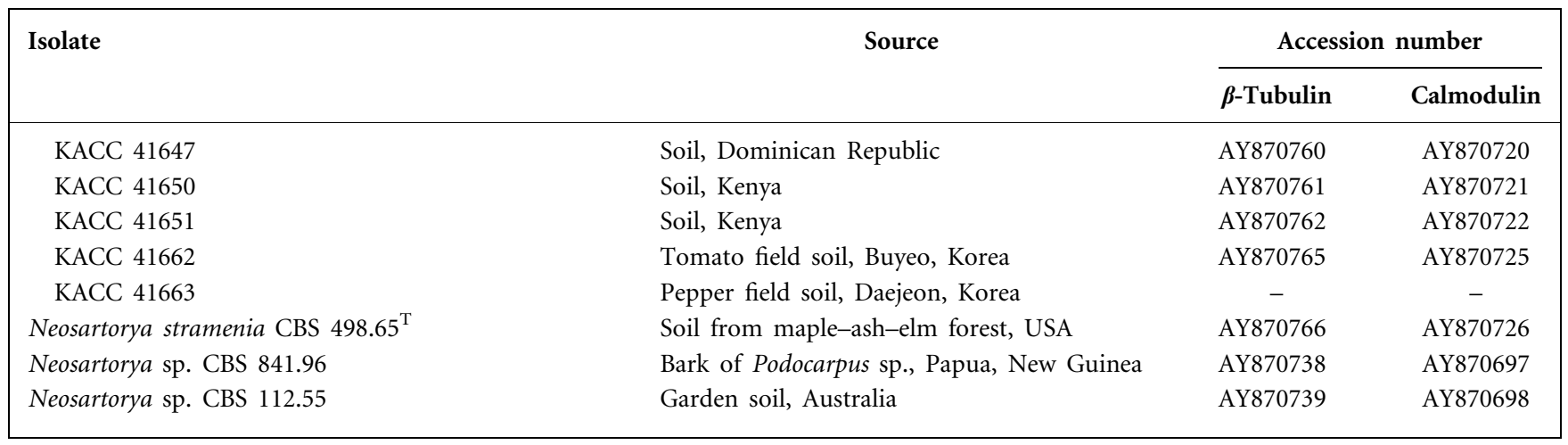

${ }^{\star}$ Sequence obtained from GenBank.

were inoculated at three points on each plate of each medium and incubated at $25^{\circ} \mathrm{C}$ in the dark for 7 days and additionally at $37^{\circ} \mathrm{C}$ on CYA. For micro-morphological observations, microscopic mounts were made in lactic acid from MEA colonies and a drop of alcohol was added to remove air bubbles and excess conidia. SEM was performed for every strain of Neosartorya used in this study using a Hitachi S570 microscope. For SEM preparation, mature cleistothecia were transferred to aluminium stubs using double-sided adhesive tape. A small drop of $10 \mathrm{mM}$ ACES buffer containing 0.05\% Tween 80 was added and the cleistothecia were crushed. The suspension was air-dried and coated with platinum.

Extrolites were analysed by HPLC using alkylphenone retention indices and diode array UV-VIS detection as described by Frisvad \& Thrane (1987), as modified by Smedsgaard (1997).

Phylogenetic analyses. Genomic DNA was extracted according to the procedure described by Lee \& Taylor (1990). A fragment of the $5^{\prime}$ portion of the $\beta$-tubulin gene was amplified using the primers bt2a and bt $2 \mathrm{~b}$ (Glass \& Donaldson, 1995). The segment of the calmodulin gene was amplified using the primers $\mathrm{cmd} 5$ ( $5^{\prime}$-CCGAGTACAAGGAGGCCTTC- $3^{\prime}$ ) and cmd6 (5'-CCGATAGAGGTCATAACGTGG-3') which were constructed in this study based on the complete Aspergillus oryzae sequence (GenBank accession number D44468). The amplified DNA fragments were purified using a QIAquick PCR purification kit (Qiagene). DNA sequences were determined using a BigDye Terminator v3.1 cycle sequencing kit (ABI) and an ABI 3100 DNA sequencer. Both strands of each fragment were sequenced.

DNA sequences were edited with the DNASTAR computer package and an alignment of the sequences was performed using the CLUSTAL $\mathrm{W}$ program (Thompson et al., 1994). The neighbour-joining (NJ) method was used for the phylogenetic analysis. For NJ analysis, the data were first analysed using the Tamura-Nei parameter distance calculation model with gamma-distributed substitution rates, which were then used to construct the NJ tree with MEGA version 2.1 (Kumar et al., 2001). To determine the support for each clade, a bootstrap analysis was performed with 1000 replications.

\section{RESULTS}

The primers bt $2 \mathrm{a}$ and bt $2 \mathrm{~b}$ amplified about 550 bp of the $5^{\prime}$ portion of the $\beta$-tubulin gene which contains introns 3,4 and 5 and exons $3,4,5$ and partial exon 6 . The phylogenetic relationships of the $\beta$-tubulin gene sequences for the 46 strains were inferred from the $\mathrm{NJ}$ analysis and the resulting phylogenetic tree is presented in Fig. 1.

The five strains of $N$. spinosa, including the ex-type strain CBS $483.65^{\mathrm{T}}$, have identical partial $\beta$-tubulin gene sequences. Strain CBS 117058 differs by only two bases from the other $N$. spinosa strains, while Neosartorya botucatensis CBS $114221^{\mathrm{T}}$ and Neosartorya paulistensis CBS $114216^{\mathrm{T}}$ have identical sequences to $N$. spinosa. $N$. spinosa showed some gene sequence similarity to N. glabra, but showed stronger similarity to the two novel taxa, which are proposed as Neosartorya coreana sp. nov. and Neosartorya laciniosa sp. nov. In this study, strains previously identified as N. glabra based on ascospore characteristics were divided into five groups. The group N. glabra sensu stricto included the ex-type strain, CBS $111.55^{\mathrm{T}}$, and clustered with Neosartorya aurata, Neosartorya stramenia, Neosartorya hiratsukae and Neosartorya fennelliae, but was placed far away from N. spinosa. Strains CBS 112.55 and CBS 841.96 showed low sequence similarity with $N$. glabra sensu stricto and were not clustered within the species. N. laciniosa, which has ascospores with a finely rough convex surface and more or less straight crests, was located near to N. spinosa. N. laciniosa differed in three (two continuous base deletions at positions 327 and 328 after primer bt2a) of 466 bases in the partial $\beta$-tubulin gene sequence compared with $N$. spinosa and the bootstrap of the grouping was only $62 \%$. N. coreana, which has ascospores with more bent equatorial crests, was also located near $N$. spinosa, but separated by a $99 \%$ bootstrap value.

The primers cmd 5 and cmd 6 amplified about 580 bp of the calmodulin gene which contains introns 2, 3 and 4 and exons 2, 3, 4 and partial exon 5. The phylogenetic relationships of the calmodulin gene sequences for the 46 strains were inferred from NJ analyses (see Supplementary Fig. S1 in IJSEM Online). In the cladogram based on the calmodulin gene sequences, $N$. laciniosa was well separated from $N$. spinosa with a bootstrap value of $98 \%$. However, there were two subgroups in this taxon. Apart from these differences, the topology of the calmodulin gene sequence phylogenetic tree was similar to that of the $\beta$-tubulin gene sequence tree. 


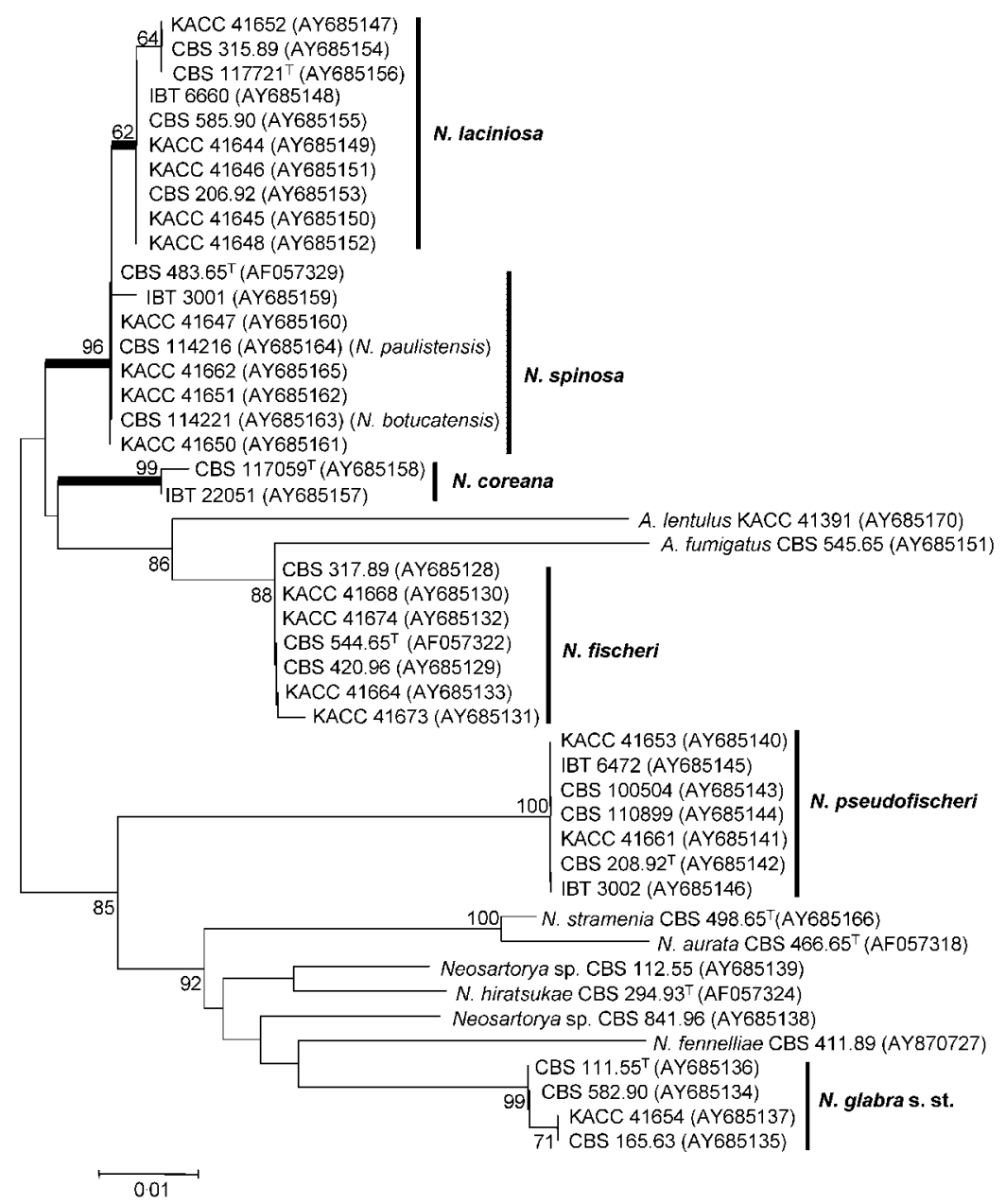

Fig. 1. Phylogenetic tree inferred from NJ analysis of partial $\beta$-tubulin gene sequences. Bootstrap values (1000 replications) are shown above or below the nodes. s. st., sensu stricto. Bar, 0.01 nucleotide changes between taxa.
On the basis of Aspergillus anamorph morphology, $N$. spinosa, N. botucatensis, N. paulistensis, N. glabra, N. laciniosa and $N$. coreana are very similar. The vesicle diameter of the six species ranges from $7 \cdot 5$ to $20 \mu \mathrm{m}$ and conidia are (sub)globose to ellipsoid, ranging from $2 \cdot 5$ to $4 \cdot 0 \mu \mathrm{m}$. The cleistothecia of $N$. glabra are yellow-white to pale yellow (2-3A2-3; Kornerup \& Wanscher, 1978), while the other three species are pale yellow to light yellow (2-3A3-4). Based on light microscopy, the ascospores of $N$. spinosa are rough, those of $N$. laciniosa and $N$. coreana are finely roughened (Figs 2 and 3) and N. glabra has nearly smooth-walled ascospores. SEM observations showed that the ascospores of $N$. spinosa CBS $483.65^{\mathrm{T}}$ have convex surfaces with distinct spines. The ascospores of N. botucatensis and N. paulistensis also have convex surfaces with spines (see Supplementary Fig. S2 in IJSEM Online). N. glabra ascospores have nearly smooth, convex surfaces with small microtuberculate projections and two straight equatorial crests. Strains of $N$. laciniosa have microtuberculate ascospores with two distinct straight crests. In the furrow, two distinct equatorial rings with small projections are present (see Supplementary Fig. S2 in IJSEM Online). N. coreana has a rugose to weak reticulate ornamentation of convex ascospores with two distinct, and often bent, crests.

Our studies of extrolites showed that N. spinosa, N. paulistensis and $N$. botucatensis produced aszonalenins, 2-pyrovoylaminobenzamide and pseurotin (Table 2). In $N$. coreana and $N$. laciniosa, aszonalenins were also present, but the other compounds were absent. All strains of $N$. laciniosa also typically produced a large number of tryptoquivalins and tryptoquivalons. Aszonalenins were also found in strains of Neosartorya fischeri, but this species produced a different extrolite profile consisting of fischerin,

Fig. 2. Neosartorya laciniosa sp. nov. CBS $117074^{\top}$. (a) Colonies on MEA after 7 days at $25^{\circ} \mathrm{C}$; (b) ascomata; (c) asci; (d, e) conidial heads; (f) ascospores under a light microscope; (g) ascospores as seen by SEM. Bars, $100 \mu \mathrm{m}$ (b) and $10 \mu \mathrm{m}$ $(\mathrm{c}-\mathrm{g})$. 

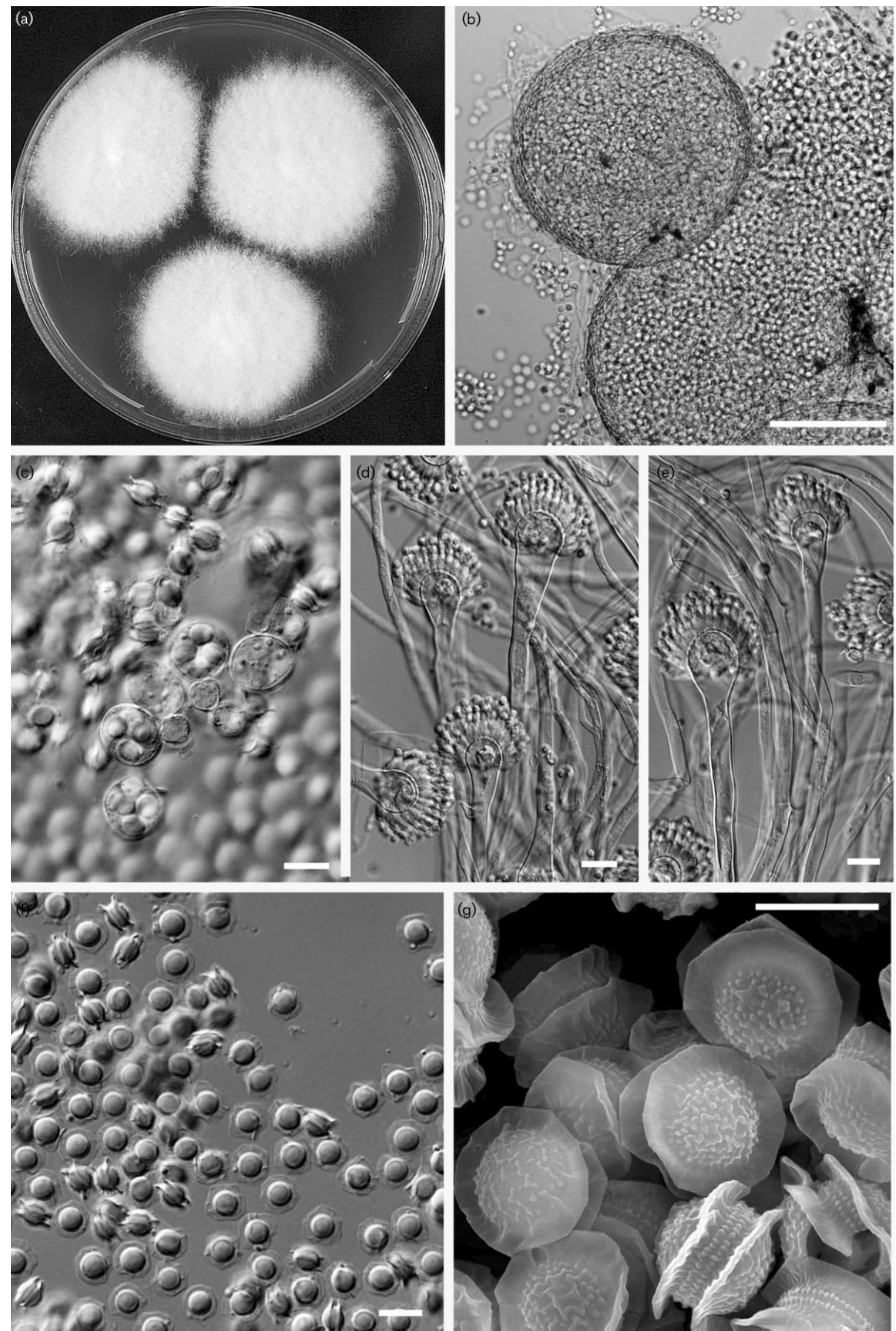

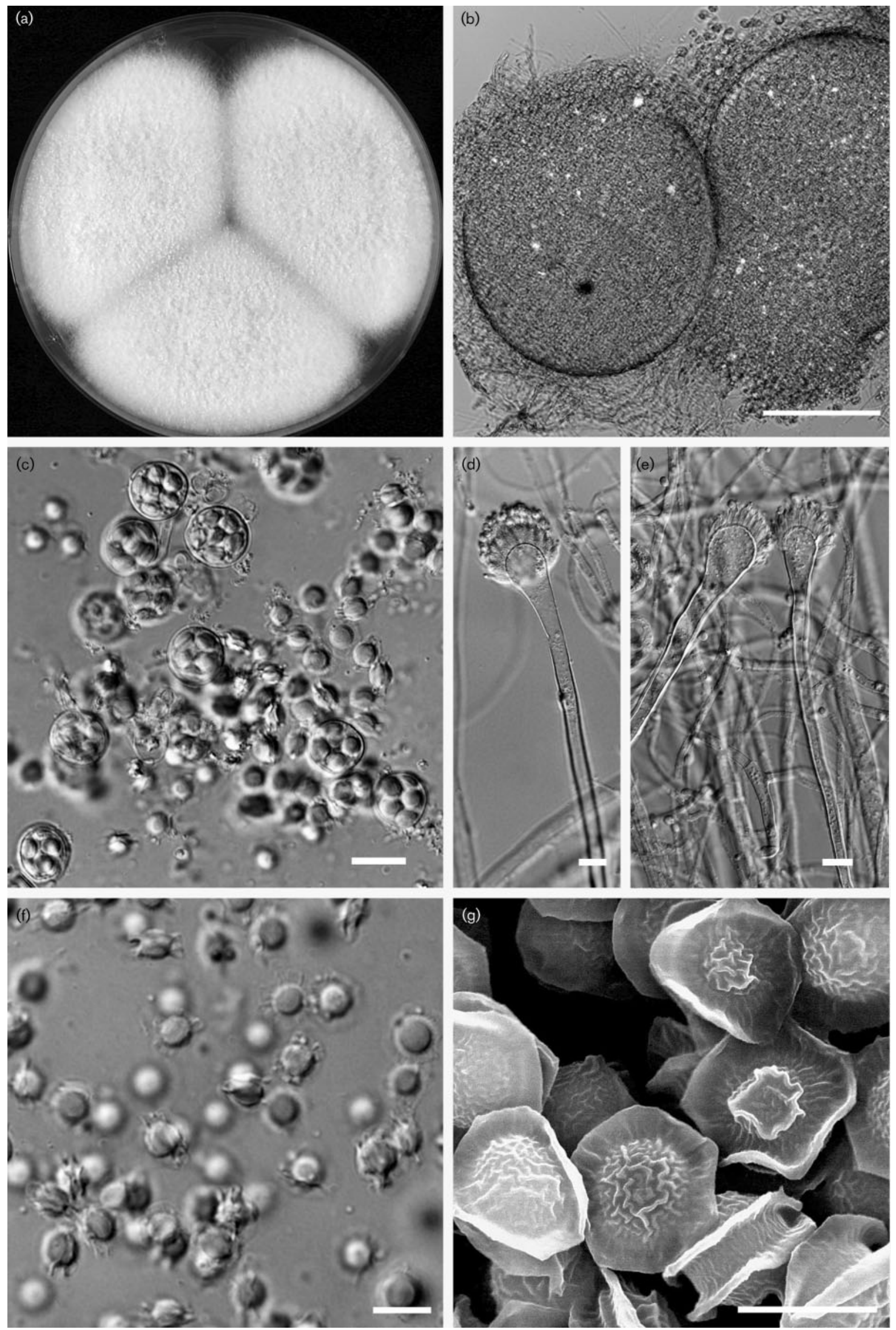
Table 2. Extrolites from Neosartorya species based on HPLC analysis of ex-type strains

The data were backed up by HPLC analyses of several further isolates of N. glabra, N. spinosa, N. laciniosa, N. fischeri and N. pseudofischeri.

\begin{tabular}{|ll|}
\hline Species & \multicolumn{1}{c|}{ Extrolites } \\
\hline N. hiratsukae & Avenaciolide \\
N. glabra & Asperpentyn, avenaciolide, wortmannin-like compound \\
N. spinosa & Aszonalenins, chrysogine, 2-pyrovoylaminobenzamide, pseurotin \\
N. paulistensis & Aszonalenins, 2-pyrovoylaminobenzamide, pseurotin \\
N. botucatensis & Aszonalenins, 2-pyrovoylaminobenzamide, pseurotin \\
N. laciniosa & Aszonalenins, tryptoquivalins, tryptoquivalons \\
N. coreana & Aszonalenins \\
N. fischeri & Aszonalenins, fischerin, neosartorin, fiscalins, helvolic acid, \\
& fumitremorgins \\
N. pseudofischeri & Asperfuran, cytochalasin-like compound, fiscalin-like compound, \\
& pyripyropens, gliotoxin \\
\end{tabular}

neosartorin, fiscalins, helvolic acid and fumitremorgins. $N$. glabra differed from the other taxa by the production of asperpentyn, avenaciolide and wortmannin.

\section{DISCUSSION}

Raper \& Fennell (1965) described Neosartorya glabra (Raper \& Fennell) Kozakiewicz as having a smooth (or nearly so), convex ascospore surface and N. spinosa (Raper \& Fennell) Kozakiewicz as having ascospores with spine-like projections ranging from $<0.5 \mu \mathrm{m}$ to as much as $2.0 \mu \mathrm{m}$. Peterson (1992) described the ascospores of Neosartorya pseudofischeri S.W. Peterson as having triangular flaps. Among the six species, N. pseudofischeri was clearly separated by the typical ascospore ornamentation, DNA-DNA hybridization (Peterson, 1992) and $\beta$-tubulin gene sequence (Geiser et al., 1998; Varga et al., 2000b). Our $\beta$-tubulin and calmodulin gene sequences confirmed that $N$. pseudofischeri is a well defined taxon. In addition, $N$. pseudofischeri produces a typical extrolite profile consisting of asperfuran, pyripyropens, gliotoxin and compounds which are similar to cytochalasins and fiscalins.

Six strains of $N$. spinosa (including CBS $483.65^{\mathrm{T}}$ ), CBS 114221 (ex-type strain of N. botucatensis) and CBS 114216 (ex-type strain of $N$. paulistensis) have almost the same $\beta$ tubulin and calmodulin gene sequences. Strain CBS 117058 differed in only two of 466 bases of the $\beta$-tubulin gene sequence when compared with the other strains. Strain KACC 41647 differed in only one of 522 bases of the calmodulin gene sequence when compared with the others. Horie et al. (1995) reported that the ascospores of N. botucatensis Horie et al. have convex surfaces with long spines up to 5 (maximum 7) $\mu \mathrm{m}$ long and $N$. paulistensis Horie et al. have convex surfaces irregularly roughened by verruculose and small triangular projections up to $1 \mu \mathrm{m}$ long. However, in our study, we have not observed that these two taxa differ significantly from $N$. spinosa with regard to their ascospore morphology and growth characteristics. Together with their phylogenetic similarity, we consider $N$. botucatensis and $N$. paulistensis to represent synonyms of $N$. spinosa.

Raper \& Fennell (1965) described N. spinosa (as Aspergillus fischeri var. spinosus) with echinulate ascospores with projections ranging from $<0.5 \mu \mathrm{m}$ to as much as $2.0 \mu \mathrm{m}$. Our observations showed that $N$. spinosa has echinulate ascospores with spines ranging from $<0.5 \mu \mathrm{m}$ to 5 (7) $\mu \mathrm{m}$ long or with verruculose and small triangular, sometimes circularly arranged, projections.

Neosartorya takakii Horie et al. was described with ascospores bearing roughly circularly arranged projections (Horie et al., 2001), a feature which has been also observed in other N. spinosa strains. This indicates that this species is a further synonym of $N$. spinosa. However, the ex-type strain of $N$. takakii could not be obtained in spite of numerous attempts. In order to establish the exact taxonomic position of N. takakii, a more detailed molecular and extrolite study of the type strain is required.

$N$. glabra strains were divided into five groups based on partial $\beta$-tubulin and calmodulin gene sequences. Of the five groups, N. glabra sensu stricto, CBS 112.55 and CBS 841.96 clustered with $N$. fennelliae, N. hiratsukae, N. stramenia and N. aurata (Fig. 1 and Supplementary Fig. S1). N. glabra sensu stricto has smaller and white cleistothecia, relatively straight equatorial crests and smoother walled convex surfaces compared with $N$. spinosa, $N$. laciniosa and $N$. coreana. N. glabra grows somewhat slower (mean diameter of

Fig. 3. Neosartorya coreana sp. nov. CBS $117059^{\top}$. (a) Colonies on MEA after 7 days at $25^{\circ} \mathrm{C}$; (b) ascomata; (c) asci; $(d, e)$ conidial heads; $(f)$ ascospores under a light microscope; $(g)$ ascospores as seen by SEM. Bars, $100 \mu \mathrm{m}(\mathrm{b})$ and $10 \mu \mathrm{m}$ $(c-g)$. 
$42-51 \mathrm{~mm}$ within 7 days at $25^{\circ} \mathrm{C}$ ) than the other species (mean diameter $41-68 \mathrm{~mm}$ within 7 days at $25^{\circ} \mathrm{C}$ ). However, at $10^{\circ} \mathrm{C}$, strains of $\mathrm{N}$. glabra grow $(6 \mathrm{~mm}$ diameter in 7 days), but the other taxa do not show growth.

CBS 112.55 isolated from garden soil in Australia was identified as N. glabra by Raper \& Fennell (1965), but with somewhat smaller ascospores and narrower, more widely separated crests. The strain produced secondary metabolites that were different from the ex-type strain of N. glabra, CBS $111.55^{\mathrm{T}}$ (Samson et al., 1990). Our study shows that CBS 112.55 has more than $5 \%$ dissimilarity based on partial $\beta$-tubulin and calmodulin gene sequences and did not group with N. glabra sensu stricto (Fig. 1 and Supplementary Fig. S1). However, the isolate did not differ from N. glabra in phenotypic characters, except that it grew somewhat slower on CYA, MEA and CZA at $25^{\circ} \mathrm{C}$ (mean diameter $25-29 \mathrm{~mm}$ in 7 days). From these results, the strain could represent a novel species, but more isolates should be available to determine its taxonomic position. Also CBS 841.96 had a special position in the cladograms based on $\beta$-tubulin and calmodulin gene sequences (Fig. 1 and Supplementary Fig. S1), but it resembled N. glabra based on phenotypic characteristics. As is the case for CBS 112.55, more isolates of CBS 841.96 will have to be studied to warrant its classification as a novel species.

Based on the $\beta$-tubulin and calmodulin gene sequence phylogeny, N. laciniosa was located distantly from N. glabra, but closer to $N$. spinosa. Its separation from $N$. spinosa was not well supported, with a bootstrap value of $62 \%$ for the $\beta$-tubulin gene sequence, but it was well supported on the basis of the calmodulin gene sequence, with a bootstrap value of $98 \%$. N. laciniosa has microtuberculate ascospores with two distinct straight crests and two distinct equatorial rings with small projections, differing from $N$. spinosa which has ascospores with long spines or roughly circularly arranged projections on the convex walls. Based on the calmodulin gene sequences, two subgroups can be distinguished; one consists of strains KACC 41652, KACC $41657^{\mathrm{T}}$, CBS 206.92 and CBS 315.89, and the second consists of strains IBT 6660, KACC 41644, KACC 41645, KACC 41646, CBS 585.90 and KACC 41648 . However, we do not consider them to represent two separate species according to the Genealogical Concordance Phylogenetic Species Recognition (Taylor et al., 2000), because CBS 206.92 cross-located in the other subgroup in the tree based on the $\beta$-tubulin gene sequence. Furthermore, no phenotypic characteristics support the separation, apart from the observation that strain IBT 6660 produced asperfuran, in contrast to the strains of the first subgroup.

$N$. coreana was located near, but clearly separated from, $N$. spinosa based on the $\beta$-tubulin and calmodulin gene sequence trees (Fig. 1 and Supplementary Fig. S1). This species had similar phenotypic characteristics to N. spinosa and $N$. laciniosa but, when observed by SEM, the species had rugose to weak reticulate ornamentation of convex ascospore walls without the two equatorial rings of microtuberculate projections and thereby differing from N. spinosa and N. laciniosa.

\section{Latin diagnosis of Neosartorya laciniosa S. B. Hong, Frisvad et Samson sp. nov.}

Anamorph: Aspergillus laciniosus S. B. Hong, Frisvad et Samson sp. nov.

Coloniae in agaro malti $53-55 \mathrm{~mm}$ diam. post 7 dies $25^{\circ} \mathrm{C}$, albae, planae, hyphis aeriis paucis superatae, margo irregularis, ascomata copiosa in zona marginali granulari. Species homothallica. Cleistothecia superficialia, alba vel dilute lutea, globosa vel subglobosa, 300-400 $\mu \mathrm{m}$ diam., post 10 hebdomades matura, hyphis hyalinis vel flavidis, $2-4 \mu \mathrm{m}$ latis laxe circumdata. Asci 8-spori, globosi vel subglobosi vel ovoidei, 11-13 $\mu \mathrm{m}$ diam., maturi evanescentes. Ascosporae late lenticulares, $4-5 \mu \mathrm{m}$, duabus crestis aequatorialibus, distantibus, ad $2 \mu \mathrm{m}$ latis circumdatae, valvae leves vel asperulatae. Conidiophora ex hyphis aeriis oriunda, stipites 3-4 $\mu \mathrm{m}$ lati; vesiculae hemisphaericae vel lageniformes, $10-14 \mu \mathrm{m}$ diam. Aspergilli uniseriati, phialides $7-8 \times 2-3 \mu \mathrm{m}$; conidia (sub)globosa, nonnumquam late ellipsoidea, levia, $2 \cdot 5-3 \cdot 5 \mu \mathrm{m}$ diam. Massa conidiorum columnaris. Metabolita aszonaleninum, tryptoquivalina, tryptoquivalona.

Typus: CBS $117721^{\mathrm{T}}\left(=\right.$ NRRL $\left.35589^{\mathrm{T}}=\operatorname{KACC} 41657^{\mathrm{T}}\right)$.

\section{Description of Neosartorya laciniosa S. B. Hong, Frisvad \& Samson sp. nov.}

Anamorph: Aspergillus laciniosus S. B. Hong, Frisvad \& Samson sp. nov.

Neosartorya laciniosa (la.cin.i.os'us. N.L. adj. laciniosus -a -um laciniate, divided into deep, narrow, irregular segments).

Rapidly growing colonies on MEA, 53-55 mm diameter in 7 days at $25^{\circ} \mathrm{C}$, white, plane, loosely overgrown by aerial hyphae, margin irregular, cleistothecia abundantly produced in marginal areas with granular appearance. Conidia heads few in number; reverse greyish orange (5B6) to yellowish orange (4B6). Colonies on CYA spread broadly, attaining a diameter of $56-58 \mathrm{~mm}$ in 7 days at $25^{\circ} \mathrm{C}$ or more than $70 \mathrm{~mm}$ in 7 days at $37^{\circ} \mathrm{C}$, more or less sulcate, white to pale yellow (2A3), granular due to the abundant production of cleistothecia, loosely overgrown by aerial hyphae; conidial heads few in number, scattered; reverse light orange (6A45). Homothallic, cleistothecia superficial, white to light yellow, globose to subglobose, $300-400 \mu \mathrm{m}$ in diameter, surrounded by a loose covering of hyaline to yellowish white, $2-4 \mu \mathrm{m}$ wide hyphae. Cleistothecial peridium hyaline to light yellow, consisting of angular, 4-15 $\mu \mathrm{m}$ diameter cells. Asci 8-spored, globose or subglobose to ovoid, 11-13 $\mu$ m diameter, evanescent at maturity. Ascospores broadly lenticular, spore body 4-5 $\mu \mathrm{m}$ diameter, provided with two distinct equatorial crests which are up to $2 \mu \mathrm{m}$ wide with two distinct equatorial rings of small projections in the ascospore furrow; convex surfaces finely rough or smooth in light microscopy, appearing rugose to tuberculate in SEM (Fig. 2). Conidial 
heads columnar. Conidiophores arising from aerial hyphae, 3-4 $\mu \mathrm{m}$ wide at the middle; vesicles subclavate, $10-14 \mu \mathrm{m}$ in diameter. Aspergilli uniseriate, phialides $7-8 \times 2-3 \mu \mathrm{m}$, covering the upper half of vesicle. Conidia, globose to subglobose, sometimes broadly elliptical, smooth, $2 \cdot 5-3 \cdot 5 \mu \mathrm{m}$ diameter. Extrolites: aszonalenins and several tryptoquivalins, tryptoquivalons; strain IBT 6660 also produces asperfuran.

The type strain, CBS $117721^{\mathrm{T}}\left(=\right.$ NRRL $35589^{\mathrm{T}}=\mathrm{KACC}$ $41657^{\mathrm{T}}$ ) (dried culture), was isolated from soil from a tomato field in Buyeo, Korea.

\section{Latin diagnosis of Neosartorya coreana S. B. Hong, Frisvad et Samson sp. nov.}

Anamorph: Aspergillus coreanus S. B. Hong, Frisvad et Samson sp. nov.

Coloniae in agaro malti $62-66 \mathrm{~mm}$ diam. post 7 dies $25^{\circ} \mathrm{C}$, albae vel luteo-albae, in medio elevatae, hyphis aeriis laxis superatae, margo irregularis, ascomata copiosa dispersa, aspectu granulari. Species homothallica. Cleistothecia superficialia, alba vel dilute lutea, post 3 hebdomades matura, globosa vel subglobosa, 200-300 $\mu \mathrm{m}$ diam., hyphis hyalinis vel flavidis, 2-3 $\mu \mathrm{m}$ latis laxe circumdata. Asci 8-spori, globosi vel subglobosi vel ovoidei, 10-13 $\mu \mathrm{m}$ diam., maturi evanescentes. Ascosporae lenticulares, 4-5 $\mu \mathrm{m}$ diam., duabus crestis aequatorialibus, distantibus, ad $2 \mu \mathrm{m}$ latis, nonnumquam irregulariter aspectu stellari dissectis circumdatae, valvae rugosae vel parce reticulatae. Conidiophora ex hyphis aeriis oriunda, stipites 3-4 $\mu \mathrm{m}$ lati; vesiculae subclavatae vel lageniformes, 8-13(-15) $\mu \mathrm{m}$ diam. Aspergilli uniseriati, phialides $6-9 \times 2-3 \mu \mathrm{m}$; conidia subglobosa vel late ellipsoidea, levia, $2 \cdot 5-3 \cdot 5 \mu \mathrm{m}$ diam. Massa conidiorum columnaris. Metabolita aszonaleninum.

Typus: CBS $117059^{\mathrm{T}}\left(=\mathrm{NRRL} 35590^{\mathrm{T}}=\mathrm{KACC} 41659^{\mathrm{T}}\right)$.

\section{Description of Neosartorya coreana S. B Hong, Frisvad \& Samson sp. nov.}

Anamorph: Aspergillus coreanus S. B. Hong, Frisvad \& Samson sp. nov.

Neosartorya coreana (co.re.an' us. N.L. adj. coreanus - $a-u m$ pertaining to Korea).

Colonies grow rapidly on MEA, $62-66 \mathrm{~mm}$ in 7 days at $25^{\circ} \mathrm{C}$, white to yellowish white $(1 \mathrm{~A} 2)$, centrally raised, loosely overgrown by aerial hyphae, irregular margin, cleistothecia produced in an irregular pattern with granular appearance. Conidial heads few in number, reverse greyish orange (5B6) to yellowish orange (4B6). Colonies on CYA spread broadly, attaining a diameter of $58-62 \mathrm{~mm}$ in 7 days at $25^{\circ} \mathrm{C}$ or more than $70 \mathrm{~mm}$ in 7 days at $37^{\circ} \mathrm{C}$, radially sulcate, white to yellowish white (1A2). Cleistothecia produced on central part and along sulcate groove, loosely overgrown by aerial hyphae; conidial heads few in number, scattered, reverse pale to light orange (5A34). Homothallic.
Cleistothecia superficial, white to light yellow (34A45) in 3 weeks, globose to subglobose, $200-300 \mu \mathrm{m}$ in diameter, surrounded by a loose covering of hyaline to yellowish white, $2-3 \mu \mathrm{m}$ wide hyphae. Cleistothecial peridium hyaline to light yellow, membranaceous, consisting of angular, 4$18 \mu \mathrm{m}$ diameter cells. Asci 8-spored, globose or subglobose to ovoid, $10-13 \mu \mathrm{m}$ diameter, evanescent at maturity. Ascospores, spore body $4-5 \mu \mathrm{m}$ diameter, provided with two well-separated, but often bent, equatorial crests which are up to $2 \mu \mathrm{m}$ wide and sometimes irregularly shaped; convex surfaces finely roughened in light microscopy appearing rugose to weakly reticulate in SEM (Fig. 3). Conidial heads columnar. Conidiophores arising from aerial hyphae, smooth, more or less sinuous, 3-4 $\mu \mathrm{m}$ wide at the middle; vesicles subclavate, $8-13$ (15) $\mu \mathrm{m}$ diameter. Aspergilli uniseriate; phialides, $6-9 \times 2-3 \mu \mathrm{m}$, covering the upper half of vesicle. Conidia subglobose to broadly elliptical, smooth, 2.5-3.5 $\mu \mathrm{m}$ diam. Extrolites: aszonalenins, pseurotin in CBS 117057 and several further metabolites for which the structure has not yet been elucidated.

The type strain, CBS $117059^{\mathrm{T}}\left(=\mathrm{NRRL} 35590^{\mathrm{T}}=\mathrm{KACC}\right.$ $41659^{\mathrm{T}}$ ) (dried culture), was isolated from soil from a tomato field in Buyeo, Korea.

\section{REFERENCES}

Feibelman, T. P., Cotty, P. J., Doster, M. A. \& Michailides, T. J. (1998). A morphologically distinct strain of Aspergillus nomius. Mycologia 90, 618-623.

Frisvad, J. C. \& Samson, R. A. (2004). Polyphasic taxonomy of Penicillium subgenus Penicillium. A guide to identification of food and air-borne terverticillate Penicillia and their mycotoxins. Stud Mycol 49, 1-173.

Frisvad, J. C. \& Thrane, U. (1987). Standardized high-performance liquid chromatography of 182 mycotoxins and other fungal metabolites based on alkylphenone retention indices and UV-VIS spectra (diode-array detection). J Chromatogr 404, 195-214.

Geiser, D. M., Frisvad, J. C. \& Taylor, J. W. (1998). Evolutionary relationships in Aspergillus section Fumigati inferred from partial $\beta$-tubulin and hydrophobin DNA sequences. Mycologia 90, 831-845.

Glass, N. L. \& Donaldson, G. C. (1995). Development of primer sets designed for use with the PCR to amplify conserved genes from filamentous ascomycetes. Appl Environ Microbiol 61, 1323-1330.

Horie, Y., Miyaji, M., Nishimura, K., Franco, M. F. \& Coelho, K. I. R. (1995). Two new species of Neosartorya from Brazilian soil. Mycoscience 36, 159-165.

Horie, Y., Abliz, P., Fukushima, K., Okada, K. \& Gusmao, N. B. (2001). Neosartorya takakii, a new species from soil in Brazil. Mycoscience 42, 91-95.

Horie, Y., Abliz, P., Fukushima, K., Okada, K. \& Takaki, G. M. C. (2003). Two new species of Neosartorya from Amazonian soil, Brazil. Mycoscience 44, 397-402.

Ito, Y., Peterson, S. W., Wicklow, D. T. \& Goto, T. (2001). Aspergillus pseudotamarii, a new aflatoxin producing species in Aspergillus section Flavi. Mycol Res 105, 233-239.

Kornerup, A. \& Wanscher, J. H. (1978). Methuen Handbook of Colour, 3rd edn. London: Eyre Methuen. 
Kozakiewicz, Z. (1989). Aspergillus fumigatus group. In Aspergillus Species on Stored Products. Mycological paper, no. 161, pp. 48-59. Wallingford, UK: CAB International.

Kumar, S., Tamura, K., Jakobsen, I. B. \& Nei, M. (2001). MEGA2: molecular evolutionary genetics analysis software. Bioinformatics 12, 1244-1245.

Lee, S. B. \& Taylor, J. W. (1990). Isolation of DNA from fungal mycelia and single spores. In PCR Protocols, a Guide to Methods and Applications, pp. 282-287. Edited by M. A. Innis, D. H. Gelfand, J. J. Sninsky \& T. J. White. San Diego: Academic Press.

Peterson, S. W. (1992). Neosartorya pseudofischeri sp. nov. and its relationship to other species in Aspergillus section Fumigati. Mycol Res 96, 547-554.

Raper, K. B. \& Fennell, D. I. (1965). Aspergillus fumigatus group. In The Genus Aspergillus, pp. 238-268. Baltimore: Williams \& Wilkins.

Rinyu, E., Varga, J., Ferenczy, L. \& Kozakiewicz, Z. (2000). Phenotypic and genotypic variability within Aspergillus section fumigatus. In Integration of Modern Taxonomic Methods for Penicillium and Aspergillus Classification, pp. 483-490. Edited by R. A. Samson \& J. I. Pitt. Amsterdam: Harwood Academic Publishers.

Samson, R. A., Nielsen, P. V. \& Frisvad, J. C. (1990). The genus Neosartorya: differentiation by scanning electron microscopy and mycotoxin profiles. In Modern Concepts in Penicillium and Aspergillus Classification, pp. 455-467. Edited by R. A. Samson \& J. I. Pitt. New York: Plenum.

Samson, R. A., Hoekstra, E. H. \& Frisvad, J. C. (2004). Introduction to Food- and Air-Borne Fungi, 7th edn. Utrecht: Centraalbureau voor Schimmelcultures.

Smedsgaard, J. (1997). Micro-scale extraction procedure for standardized screening of fungal metabolite production in cultures. J Chromatogr A 760, 264-270.

Taylor, J. W., Jacobson, D. J., Kroken, S., Kasuga, T., Geiser, D. M., Hibbett, D. S. \& Fisher, M. C. (2000). Phylogenetic species recognition and species concepts in fungi. Fungal Genet Biol 31, 21-32.

Thompson, J. D., Higgins, D. G. \& Gibson, T. J. (1994). CLUSTAL W: improving the sensitivity of progressive multiple sequence alignment through sequence weighting, position-specific gap penalties and weight matrix choice. Nucleic Acids Res 22, 4673-4680.

Varga, J., Toth, B., Rigo, K., Debets, F. \& Kozakiewicz, Z. (2000a). Genetic variability within the Aspergillus viridinutans species. Folia Microbiol (Praha) 45, 423-428.

Varga, J., Vida, Z., Toth, B., Debets, F. \& Horie, Y. (2000b). Phylogenetic analysis of newly described Neosartorya species. Antonie van Leeuwenhoek 77, 235-239. 